\title{
Elemental Characterization of Aerosols in Wet Deposition along a Dense Traffic Highway in Ogbomoso, Nigeria
}

\author{
A.O. Alamu ${ }^{1}$, A.O. Alade ${ }^{1,3}$, S.A. Adebanjo ${ }^{2 *}$ L.A. Jimoda ${ }^{1}$, \\ ${ }^{1}$ Department of Chemical Engineering, Ladoke Akintola University of Technology, Ogbomoso, Nigeria. \\ ${ }^{2}$ Department of Chemical Engineering Department, Lagos State University, Epe Campus, Lagos, Nigeria. \\ ${ }^{3}$ Bioenvironmental, Water and Engineering Research Group (BWERG), Ladoke Akintola University of \\ Technology Ogbomoso, Nigeria \\ *e-mail: Sunday.adebanjo@lasu.edu.ng
}

Received: 23rd June 2019

Accepted: $11^{\text {th }}$ December 2019

Published: $31^{\text {st }}$ March 2020

https://doi.org/10.47545/etrj.2020.5.1.055

\begin{abstract}
Atmospheric samples of wet deposition were collected at seven sampling locations along a dense traffic highway in Ogbomoso, Nigeria for one month. Wet deposition flux evaluated ranged from 0.4926-0.6015 $\mu \mathrm{g} / \mathrm{m}^{2} . d$. Particulate matters samples were analyzed for ten trace metals through Atomic Absorption Spectrophotometer (AAS). Trace metals were extracted from filters with digestion method using a mixture of $\mathrm{HNO}_{3}$ and $\mathrm{H}_{2} \mathrm{O}_{2}$. The average concentration of the trace metals: $\mathrm{Cd}, \mathrm{Cr}, \mathrm{Mn}, \mathrm{Pb}, \mathrm{Zn}, \mathrm{Cu}, \mathrm{AS}, \mathrm{Ca}, \mathrm{Ni}$ and $\mathrm{Fe}$, in wet deposition were 45.42, 52.46, 15.29, 71.23, 458.9, 747.2, 22.92, 291.3, 63.32, 744.2 $\mu \mathrm{g} / \mathrm{m}^{3}$ respectively. These concentrations were higher than WHO and FEPA standard limits of trace metals in air. The mean concentrations of trace metals in wet deposition were found in the order of $\mathrm{Cu}>\mathrm{Fe}>\mathrm{Zn}>\mathrm{Ca}>\mathrm{Pb}>\mathrm{Ni}>\mathrm{Cr}>\mathrm{Cd}>\mathrm{As}>\mathrm{Mn}$. Correlation studies showed that the trace metals originated from common source along the highway: Cd was highly correlated with $\mathrm{Cr}$ $(r=0.7607), \mathrm{Cr}$ was highly correlated with $\mathrm{Zn}(r=0.912), \mathrm{Pb}$ with $\mathrm{Cu}(r=0.9559), \mathrm{Ca}(r=0.7632)$ and $\mathrm{Ni}$ ( $r=0.9114)$. Enrichment factor analysis showed that $\mathrm{Cd}, \mathrm{Cr} \mathrm{Zn}, \mathrm{Cu}, \mathrm{As} \mathrm{Pb}$ and Ni originated from anthropogenic sources, majorly traffic and industrial activities while Fe and Ca were of crustal origin.
\end{abstract}

Keywords: Anthropogenic, Highway, Particulate matter. Trace metals, Wet deposition

\section{INTRODUCTION}

The urban atmosphere is exposed to various atmospheric pollutants, which include a range of chemical species, ranging from metals to organic and inorganic compounds [1,2]. Trace metals are important inorganic compounds emitted from natural sources as well as anthropogenic activities [3-5]. The natural sources include windborne dust, sea spray, volcanic activities and biomass burning, while emissions of particles attributable to human activities arise primarily from sources such as fuel combustion, industrial processes, non-industrial sources and traffic emissions [6-8]. Some of these trace metals, particularly, $\mathrm{Ca}, \mathrm{As}, \mathrm{Cd}, \mathrm{Cu}, \mathrm{Fe}, \mathrm{Pb}, \mathrm{Zn}, \mathrm{Cr}, \mathrm{Ni}$, and $\mathrm{Mn}$ are classified to be of major concern, because of their persistence in the environment, toxicity, potential carcinogenic characteristics, and increased mortality rates [9-17]. Traffic related emissions have been identified as one of the most significant sources contributing to urban air pollution $[3,18,19]$. Non-crustal elements associated with particulate matter near the highways mostly come from vehicle emissions [20,21]. Studies conducted on vehicular emissions along highway in several urban regions such as New Jersey, (US), Helsinki Metropolitan area (Finland) and Dhaka, (Bangladesh) have shown that the concentration of trace elements varied as a function of distance from highway [22-25].

Ogbomoso axis of Ibadan-Ilorin highway being a major route linking northern and southern region of Nigeria has witnessed an increased traffic level by cars and motor cycles due to the influx of both staff and students to the University and the University Teaching Hospital, which were not in existence some years ago, coupled with traffic flow of heavy trucks. In addition, the government has opened up road construction work along the highway for more than three years and the roads have not been well covered with bitumen. All these have given rise to high traffic emission and dust generation along the highway. Although, deposition of aerosols in urban areas is widely recognized, only few studies have been devoted to the Ogbomoso area. Yet the reported studies focused on gases in aerosols [26], while those that focused on trace metals used soil and vegetation as the study media [27]. Hence, there is need to investigate wet deposition and characterize trace metals associated with wet deposition of aerosols along the highway. This research aimed at investigating the characteristics of wet deposited aerosols along Ogbomoso Section of Ibadan - Ilorin highway. 


\section{MATERIALS AND METHODS}

\subsection{Sampling site and sampling procedures}

Sampling site: The Ogbomoso city is a pre-colonial urban center and the second largest city, both in terms of population and spatial extent, in Oyo State, Nigeria. The city is situated in South-Western Nigeria (4 $4^{\circ} 16^{\prime} 0$ " East; $8^{\circ} 8^{\prime} 0 "$ North) Fig.1. It is located at a distance of about $100 \mathrm{~km}$ north of Ibadan, the Oyo State capital, and about $52 \mathrm{~km}$ from Ilorin, Kwara State capital. The study area (Figure 1) is one of the important gateways to the Northern part of Nigeria from the Yoruba land. It develops laterally towards the north and south along the Ibadan-Ilorin road ${ }^{28}$. The city is characterized by two distinct seasons: dry (November - February) and wet (March - October) with a mean annual rainfall of $1200 \mathrm{~mm}$ distributed seasonally. Temperature ranges are small and constant throughout the year. Its hottest month records $32.48{ }^{\circ} \mathrm{C}\left(90{ }^{\circ} \mathrm{F}\right)$ and its coolest month $26.88^{\circ} \mathrm{C}\left(70{ }^{\circ} \mathrm{F}\right)$ with the temperature range of not more than $8^{\circ} \mathrm{C}\left(20^{\circ} \mathrm{F}\right)$. Being located along Ibadan - Oyo - Ilorin route, Ogbomoso has witnessed growth in road traffic [26]. There has not been an increase in industrial activities along the highway. Major industries in the town include small agricultural processing industries, welders' workshop, paint and pharmaceutical industries. On the other hand, there has been an increase in the number of vehicles for personal and commercial use in the town. Thus, traffic emission

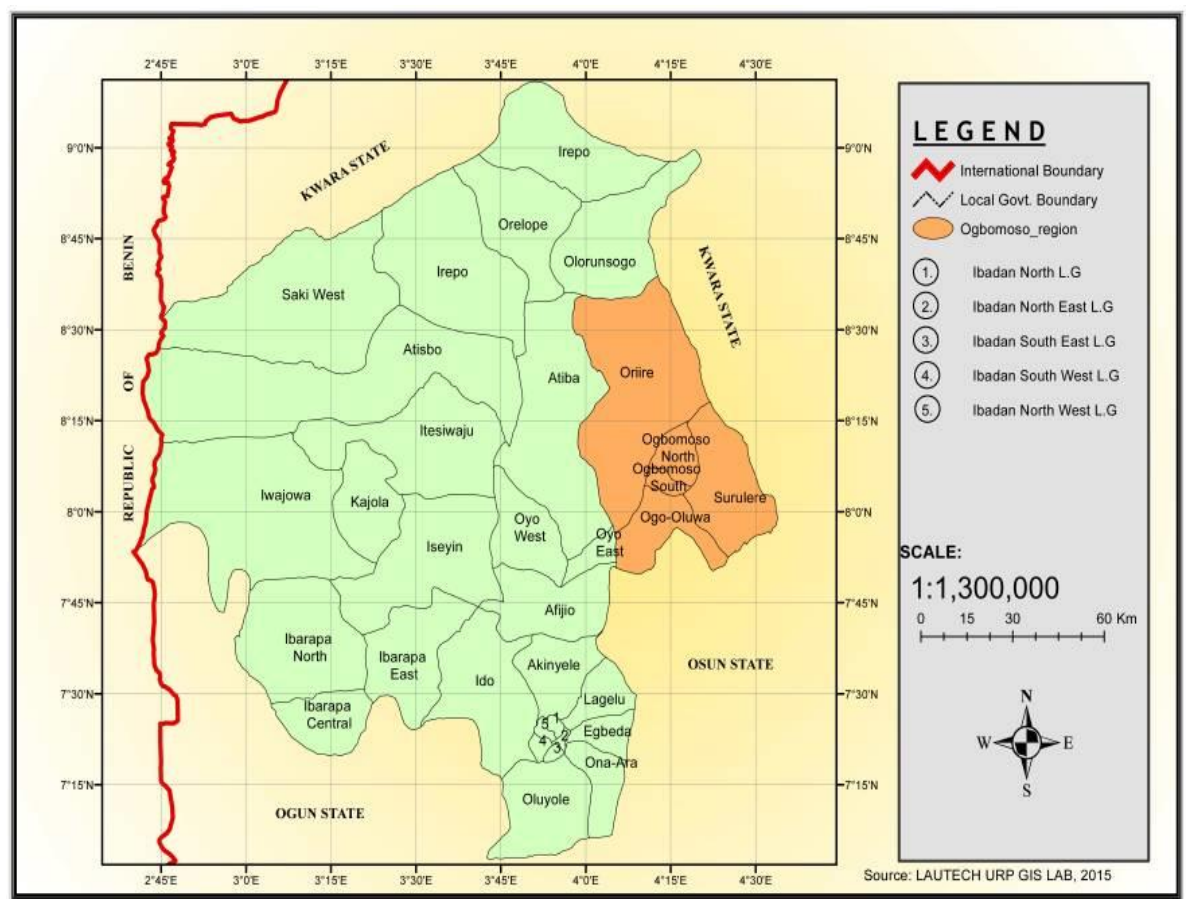

Fig. 1: Location of Ogbomoso in Oyo State.

and road dust are expected to be the major sources of air pollution along the highway. The selection of the sampling site was based on several factors including nearness to the highway, safety of the deposition guages, minimizing potential for sample contamination, and ease of access. Based on the above criteria, seven sampling spots were chosen along Ogbomoso section of Ibadan-Ilorin highway. The characteristics of the sampling spots are given in Table 1. This research work was carried out along Ibadan- Ilorin highway that spans Ogbomoso township. Wet deposition samples were collected, filtered, and wet deposition fluxes of trace metals were evaluated considering the collection area and sampling period. The filters were analyzed for ten trace metals using Atomic Absorption Spectrometry (AAS).

Sampling procedure: Wet deposition samples were collected for thirty days in in the month of October. All the filters used to collect samples were kept in a desiccator for $2 \mathrm{hrs}$ before use for conditioning. The weight of the conditioned filters were measured by a microbalance before use. The loaded filters were encased in sealed plastic 
bag to minimize contamination and kept in freezer until chemical analysis to limit losses of volatile components [25]. Filter blanks were stored and processed in an identical manner as the loaded filters.

Wet deposition samples were collected with the use of deposition gauges, each of dimension $0.2 \mathrm{~m}$ diameter by $0.15 \mathrm{~m}$ depth at the seven sampling spots during the raining season [29-31]. The gauges were positioned inbetween the pillar rods on the upper deck of some buildings along the highway. The buildings were approximately 3-14 $\mathrm{m}$ above the ground to avoid collection of local emissions such as re-suspended particles [32]. The gauges were exposed for one month during the sampling period in order to measure the flux of settle-able particulate matter.

Table 1: Characteristics of the Sampling Locations

\begin{tabular}{|c|c|c|c|c|}
\hline $\begin{array}{l}\text { Sampling } \\
\text { location }\end{array}$ & $\begin{array}{l}\text { a Height } \\
\text { (m) }\end{array}$ & $\begin{array}{l}\text { b Distance } \\
\text { (m) }\end{array}$ & Description & Industrial Activities \\
\hline High school & 3.5 & 12.5 & $\begin{array}{l}\text { Intersection with high } \\
\text { traffic }\end{array}$ & \\
\hline Idi Oro & 4.8 & 6.7 & Medium traffic & welding, fuel service station \\
\hline California & 10.6 & 16 & Medium traffic & Welding \\
\hline Olopemarun & 5 & 15.3 & Medium traffic & welding, animal feed processing \\
\hline Takie & 7.4 & 4.2 & High traffic & $\begin{array}{l}\text { fuel service station, motor park, road } \\
\text { construction, market }\end{array}$ \\
\hline Starlight & 4.67 & 16.9 & High traffic & Fuel service station, motor park. \\
\hline Sabo & 6.5 & 5.8 & High traffic & Market \\
\hline
\end{tabular}

${ }^{\mathrm{a}}$ Height of the sampling location (m) and ${ }^{\mathrm{b}}$ Distance from the highway (m)

The height of the opening area of the collector was at least $1.5 \mathrm{~m}$ above ground in order to avoid sample contamination by soil particles during heavy rains. All parts of collectors were made in inert material such as high-density polyethylene (HDPE), in order to avoid metals contaminations and the sample containers were cleaned prior to sampling with distilled water and a $1 \%$ nitric acid solution to eliminate particles deposited or adsorbed onto container walls [33-35]. The rainwater in the gauges were collected and then filtered through a dry and pre-weighed Whatman-41 filter paper. The net aerosol load on the filter papers were determined by weighing the filter papers with a microbalance before and after filtration. The filters were dried in a desiccator to a constant weight and then re-weighed to determine change in the weight of the filter. The loaded filters were then placed in an aluminium foil and a zip-lock bag until analysis [36].

\subsection{Measurement of Wet Deposition Flux of Aerosols}

The wet deposition flux of aerosol was calculated as weight deposited per unit area per unit time [37].

Wet depositon Flux $=\frac{W_{p}}{A . t}$

Where: $\mathrm{Wp}=$ Weight of particulate matter in $\mu \mathrm{g}, \mathrm{A}=$ Area of the deposition gauge in $\mathrm{m}^{2}$ and $\mathrm{t}=$ Duration of exposure in day.

\subsection{Determination of Elemental Composition}

The filters were digested using a mixture of nitric acid $\left(\mathrm{HNO}_{3}\right)$ and perchloric acid $\left(\mathrm{HClO}_{3}\right)$ in ratio 2:1 [38]. The content was heated on a hot plate at $105{ }^{\circ} \mathrm{C}$ for about 1 hour until the colour changed from reddish brown to colourless under a fume cupboard. The solution was cooled to room temperature, filtered with a Whatman No. 42 filter paper and made up to $25 \mathrm{ml}$ with distilled water. The digest $(25 \mathrm{ml})$ was used to determine the concentrations of the selected trace metals ( $\mathrm{Ca}, \mathrm{As}, \mathrm{Cd}, \mathrm{Cu}, \mathrm{Fe}, \mathrm{Pb}, \mathrm{Zn}, \mathrm{Cr}$, Ni and $\mathrm{Mn}$ ) using Atomic Absorption Spectrometer (AAS Buck Scientific VGP 210 Model) at the Centre for Energy Research and Development (CERD) at Obafemi Awolowo University, Ile Ife, Nigeria. The instrument was calibrated with appropriate standards to obtain calibration curves. The blank filters were treated in a similar manner. 


\subsection{Evaluation of Trace Metals Enrichment Factor}

The observed concentrations of trace metals in wet deposition should be explained by natural sources in the absence of anthropogenic sources. However, emissions from the various man-made sources have drastically increased concentrations of metals in our environment. To identify the origin of trace metals in precipitation, enrichment factors $(\mathrm{EF})$ are normally applied, to show the degree of enrichment of a given element compared to the relative abundance of that element in crustal material [39-41]. $\mathrm{Na}, \mathrm{K}, \mathrm{Al}, \mathrm{Mg}, \mathrm{Ca}, \mathrm{Mn}$ and Fe are used as the reference metals in most cases. Concentration of trace metals detected in wet deposition samples were correlated and Fe showed the best correlation with all other metals hence, selected as the reference element $[42,43]$. Efs < 10 indicate metals having crustal origin; $10<$ Efs $<100$ indicate moderate anthropogenic enrichment, showing greater concentrations of a particular metal in the precipitation than would be expected from the crustal origin and metals with Efs $>100$ are considered to be of anthropogenic origin [44].

The enrichment factor for wet deposition was calculated using Equation (2.2)

$$
E F(X)=\frac{(X / F e)_{\text {precipitation }}}{(X / F e)_{\text {Crust }}}
$$

Where: $E F(X)=$ enrichment factor, $(X / F e)_{\text {precipitation }}=$ mean concentrations of the target element and $\mathrm{Fe}$ in precipitation, and $(X / F e)_{C r u s t}=$ mean concentrations of the target element and $\mathrm{Fe}$ in continental crust.

\section{RESULTS AND DISCUSSION}

\subsection{Wet Deposition Fluxes of Aerosols along the Highway}

Wet deposition flux of aerosol measured along the highway were $0.4962,0.4853,0.4461,0.4694,0.6015,0.5938$, $0.5915 \mu \mathrm{g} / \mathrm{m}^{2}$.d for High School, Idi Oro, California, Olopemarun, Takie, Starlight and Sabo, respectively (Fig.2). The measured deposition flux ranged from $0.4461 \mu \mathrm{g} / \mathrm{m}^{2} . \mathrm{d}$ at California to $0.6015 \mu \mathrm{g} / \mathrm{m}^{2} . \mathrm{d}$ at Takie. Anthropogenic sources like traffic-related emissions and construction activities could be responsible for higher deposition flux at Takie than the other sampling locations along the highway. This implied that Takie was more polluted than the remaining sampling locations.

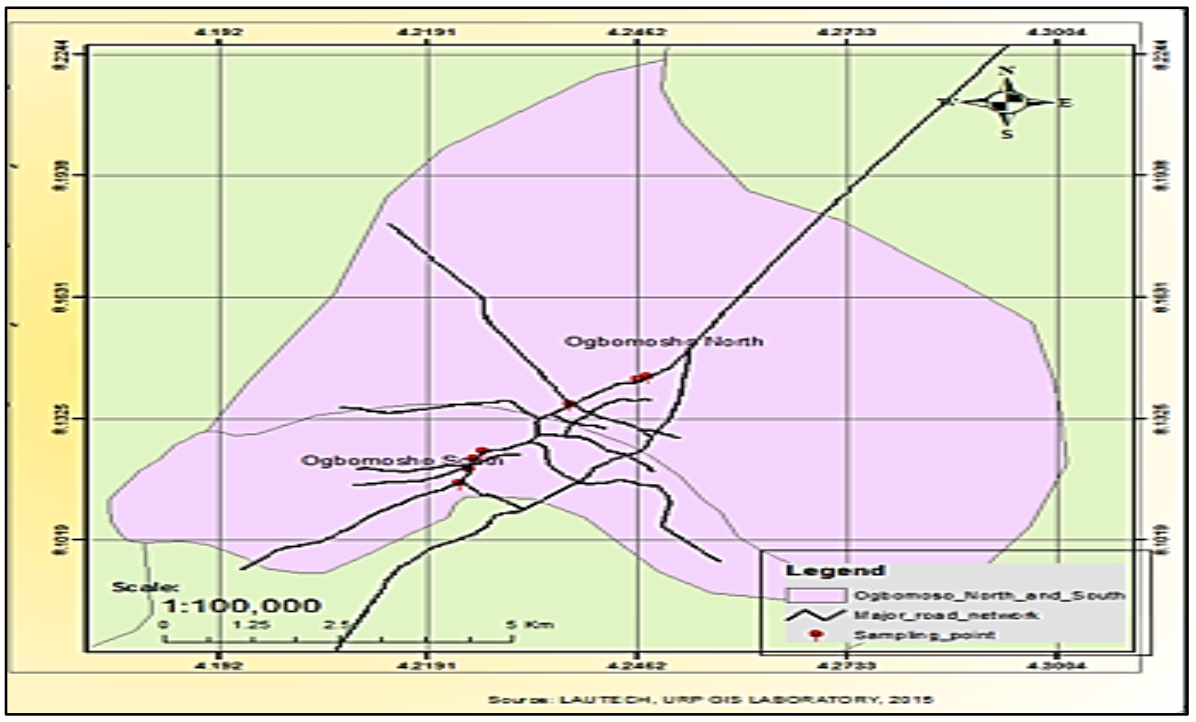

Fig.2: Sampling Locations along Ogbomoso Section of Ibadan-Ilorin Highway.

\subsection{Concentration of Trace Metals in Wet Deposition}

The concentrations of $\mathrm{Cd}, \mathrm{Cr}, \mathrm{Mn}, \mathrm{Pb}, \mathrm{Zn}, \mathrm{Cu}, \mathrm{AS}, \mathrm{Ca}, \mathrm{Ni}$ and $\mathrm{Fe}$, were in the ranges $31.19-64.23 \mu \mathrm{g} / \mathrm{m}^{3}, 10.61-$ $87.02 \mu \mathrm{g} / \mathrm{m}^{3}, 8.27-22.45 \mu \mathrm{g} / \mathrm{m}^{3}, 60.45-88.71 \mu \mathrm{g} / \mathrm{m}^{3}, 281-620.82 \mu \mathrm{g} / \mathrm{m}^{3}, 549.47-969.35 \mu \mathrm{g} / \mathrm{m}^{3}, 13.47-30.61 \mu \mathrm{g} / \mathrm{m}^{3}$, $213.88-403.26 \mu \mathrm{g} / \mathrm{m}^{3}, 38.34-86.25 \mu \mathrm{g} / \mathrm{m}^{3}$ and $623.99-930.28 \mu \mathrm{g} / \mathrm{m}^{3}$, respectively, at the seven sampling spots along the highway (Table 2). 
The order of abundance of the heavy metals, based on the average quantification, is given as $\mathrm{Cu}>\mathrm{Fe}>\mathrm{Zn}>\mathrm{Ca}$ $>\mathrm{Pb}>\mathrm{Ni}>\mathrm{Cr}>\mathrm{Cd}>\mathrm{As}>\mathrm{Mn}$. The highest $\left(64.23 \mu \mathrm{g} / \mathrm{m}^{3}\right)$ and lowest $\left(31.20 \mu \mathrm{g} / \mathrm{m}^{3}\right)$ concentrations of Cd were detected at Takie and California, respectively. These concentrations are above the WHO, EPA and ATSDR standard value of $0.005-0.5 \mu \mathrm{g} / \mathrm{m}^{3}$ [44-46] (Table 3). The presence of $\mathrm{Cd}$ in the environment could be from natural sources but the other possible sources of $\mathrm{Cd}$ in this study may be through anthropogenic activities. Fatoba et al., [47] concluded that the presence of industries and several combustion processes like the car emissions contributed to the atmospheric Cd in the study area. Arditsoglou and Samara [6] reported wear of the brake lining and of other metallic parts of vehicles as the major source of $\mathrm{Cd}$ in the environment. In the study carried out by Moaref et al., [48], it was also discovered that the most concentration levels of Cd were recorded in traffic zone. Scerbo et al. [49] (2010) reported that Cd in the environment is traced to Di-methyl cadmium used in the production of tetraethyl lead and its emission can be traced to vehicles.

The higher concentrations of $\mathrm{Cr}$ at Takie $\left(87.02 \mu \mathrm{g} / \mathrm{m}^{3}\right)$ and starlight $\left(74.29 \mu \mathrm{g} / \mathrm{m}^{3}\right)$ than those obtained at the other sampling locations along the highway could be attributed to the elevated concentrations of these metals in the atmosphere at these spots. These concentrations in wet deposition are above EPA standard value of 0.006 $\mu \mathrm{g} / \mathrm{m}^{3}$ [46] (Table 3). Gunawardena et al.,[50] attributed the high concentrations of $\mathrm{Cr}$ in bulk depositions to the elevated concentrations of these metals in the atmosphere.

Table 2. Concentration of Trace Metals in wet deposition along the Highway

\begin{tabular}{|c|c|c|c|c|c|c|c|c|c|c|}
\hline \multirow{2}{*}{$\begin{array}{l}\text { Sampling } \\
\text { Locations }\end{array}$} & \multicolumn{7}{|c|}{ Trace metals $\left(\mu \mathrm{g} / \mathrm{m}^{3}\right)$} & \multirow[b]{2}{*}{$\mathrm{Ca}$} & \multirow[b]{2}{*}{$\mathrm{Ni}$} & \multirow[b]{2}{*}{$\mathrm{Fe}$} \\
\hline & $\mathrm{Cd}$ & $\mathrm{Cr}$ & $\mathrm{Mn}$ & $\mathrm{Pb}$ & $\mathrm{Zn}$ & $\mathrm{Cu}$ & As & & & \\
\hline High School & 45.88 & 38.20 & 11.23 & 76.04 & 302.5 & 756.8 & 21.43 & 225.3 & 74.27 & 623.9 \\
\hline 1Idi Oro & 50.47 & 63.67 & 17.96 & 65.14 & 493.5 & 715.4 & 30.61 & 238.4 & 62.30 & 658.3 \\
\hline California & 31.20 & 10.61 & 13.47 & 60.45 & 281.2 & 549.5 & 15.31 & 213.9 & 38.34 & 626.3 \\
\hline Olopemarun & 41.29 & 27.53 & 13.47 & 67.59 & 435.1 & 710.2 & 18.37 & 305.3 & 47.92 & 790.9 \\
\hline Takie & 64.23 & 87.02 & 22.45 & 88.71 & 620.8 & 969.4 & 36.74 & 403.3 & 86.25 & 930.3 \\
\hline Starlight & 48.17 & 74.29 & 20.20 & 76.04 & 557.1 & 826.8 & 24.49 & 375.5 & 76.67 & 898.3 \\
\hline Sabo & 36.70 & 65.92 & 8.265 & 67.59 & 522.7 & 702.4 & 13.47 & 277.6 & 57.50 & 681.1 \\
\hline Average & 45.42 & 52.46 & 15.29 & 71.23 & 458.9 & 747.2 & 22.92 & 291.3 & 63.32 & 744.2 \\
\hline
\end{tabular}

Lead is one of the major trace elements in urban environment due to its long residence time in the environment [51]. The average concentration of $\mathrm{Pb}\left(71.23 \mu \mathrm{g} / \mathrm{m}^{3}\right)$ in wet deposition is

Table 3: Comparison of Concentration of Trace Metals with Regulatory Standards

\begin{tabular}{|c|c|c|c|c|c|c|c|c|c|c|}
\hline \multirow[t]{2}{*}{ Body } & \multicolumn{10}{|c|}{ Trace Metals $\left(\mu \mathrm{g} / \mathrm{m}^{3}\right)$} \\
\hline & $\mathrm{Cd}$ & $\mathrm{Cr}$ & $\mathrm{Mn}$ & $\mathrm{Pb}$ & $\mathrm{Zn}$ & $\mathrm{Cu}$ & As & $\mathrm{Ca}$ & $\mathrm{Ni}$ & $\mathrm{Fe}$ \\
\hline $\mathrm{WHO}^{\mathrm{a}}$ & $\begin{array}{l}0.005- \\
0.5\end{array}$ & NA & 0.150 & NA & NA & NA & 0.007 & NA & 0.02 & NA \\
\hline $\mathrm{EPA}^{\mathrm{b}}$ & 0.006 & 0.006 & NA & 1.500 & 0.103 & 0.290 & NA & NA & NA & NA \\
\hline $\operatorname{ATSDR}^{\mathrm{c}}$ & 0.005 & NA & NA & 0.500 & NA & NA & NA & NA & NA & NA \\
\hline $\begin{array}{l}\text { This } \\
\text { Study }\end{array}$ & 45.42 & 52.46 & 15.29 & 71.23 & 458.9 & 747.2 & 22.92 & 291.3 & 63.3 & 744.2 \\
\hline
\end{tabular}

${ }^{\mathrm{a} W H O}[44] ;{ }^{\mathrm{b}} \mathrm{EPA}[46] ;{ }^{\mathrm{c} A T S D R}[45] ;$ NA(Not Available)

higher than EPA standard value of $1.50 \mu \mathrm{g} / \mathrm{m}^{3}{ }^{46}$ and $0.50 \mu \mathrm{g} / \mathrm{m}^{3}$ [45] (Table 3). The presence of Pb in the environment could be due to several emission sources such as carbon black plant, non-ferrous metal smelting, steel and pipe manufacturing plants, gas flare burning and heavy traffic of vehicles [48]. However, the presence of $\mathrm{Pb}$ in wet deposition along Ogbomoso section of Ibadan- Ilorin highway could be attributed to heavy traffic of vehicles since most of these industrial activities are rare along the highway. Meena et al., [52] reported that concentration of $\mathrm{Pb}$ in wet deposition was high in zones with higher anthropogenic activities such as heavy traffic of vehicles. The study showed that $\mathrm{Pb}$ concentration in wet precipitation was due to the effects of industrial and traffic activities on rain chemistry in urban area. Fatoba et al., [47] also noted that high concentration of $\mathrm{Pb}$ was always associated with high traffic density in some parts of Ogun State.

The primary source of $\mathrm{Zn}$ along Ogbomoso section of Ibadan-Ilorin highway may be probably from motor vehicle tyre wear caused by poor road surfaces, and the lubricating oils in which $\mathrm{Zn}$ is found as part of many additives 
such as zinc Dithiophosphates because no major industry such as smelting, exist along the study area [53]. Moaref et al., [48] reported that the highest levels of $\mathrm{Zn}$ in wet deposition were shown in traffic and industrial stations.

Gunawardena et al.,[50] attributed the high concentrations of $\mathrm{Zn}$ in bulk depositions to the elevated concentrations of this metal in the atmosphere. Xia and Gao [22], as well as Councell et al., [54] have noted that tyre wear is one of the primary sources of $\mathrm{Zn}$ in the urban atmosphere. The fact that $\mathrm{Zn}$ primarily originates from the wear of vehicle tyre and other components can be further supported by the findings from the studies undertaken by Bai et al., [53], Councell et al., [54] and Adedeji et al., [55]. The average concentration of $\mathrm{Zn}\left(458.9 \mu \mathrm{g} / \mathrm{m}^{3}\right)$ in wet deposition is higher than EPA standard value of $0.103 \mu \mathrm{g} / \mathrm{m}^{3}$ [46] (Table 3).

The average concentration of $\mathrm{Cu}\left(747.2 \mu \mathrm{g} / \mathrm{m}^{3}\right)$ in wet deposition is higher than EPA standard value of 0.290 $\mu \mathrm{g} / \mathrm{m}^{3}$ [46] (Table 3). High Copper concentration in wet deposition along the highway could be due to vehicular emissions in the environment. Farmaki and Thomaidis, [56] attributed the presence of $\mathrm{Cu}$ to vehicular emissions or oil combustion and re-suspended road dust. Wang et al., [57] also attributed the presence of copper to chemical industries and intensive traffics. Most of man-made emissions of As originate from metal smelters which is emitted in form of arsenites or arsenates whereas natural sources are from volcanic activities. These activities are rare in the study areas and this explains the low concentration of As in the environment.

$\mathrm{Ni}$ pollution along the highway could result from the combustion of coal, diesel oil and fuel oil. Natural sources of atmospheric nickel include wind-blown dust, derived from the weathering of rocks and soils, volcanic emissions, forest fires and vegetation [58]. The average concentration of Ni $\left(63.32 \mu \mathrm{g} / \mathrm{m}^{3}\right)$ in wet deposition is above the WHO standard value of $0.020 \mu \mathrm{g} / \mathrm{m}^{3}$ [44] (Table 3). Fe highest $\left(930.3 \mu \mathrm{g} / \mathrm{m}^{3}\right)$ and lowest $\left(623.9 \mu \mathrm{g} / \mathrm{m}^{3}\right)$ concentrations were detected at Takie and High School, respectively. The presence of Fe in the particulate from the wet deposition along the highway could be due to the natural origin of the studied area and tear of certain parts of vehicles moving on the road. It can also be from dropping of metal scraps by the roadsides. Adefemi et al., [59] attributed a very high concentration of Fe to the occurrence of Fe at high concentrations in Nigerian soils, while Vallius [60] also reported the presence of Fe in emissions from heavy-duty vehicles

\subsection{Pearson's correlation matrix among the trace metals measured in wet deposition}

Correlation coefficient is a measure of the linear correlation between two variables and giving a value between +1 and -1 . Where 1 is total positive correlation, 0 is no correlation, and -1 is the total negative correlation. It is usually performed to distinguish the possible common sources of constituents [25, 31].

The Pearson's correlation matrix among the trace metals measured in wet deposition along Ogbomoso section of Ibadan-Ilorin Highway are presented in Table 4. All positive and strong correlations indicate relationship among the trace metals in the same trend such that increase in the concentration of any suggests increase in concentration of the other. Concentration of Cd was moderately correlated with $\mathrm{Cr}(\mathrm{r}=0.7607)$ and $\mathrm{Mn}(\mathrm{r}=0.7823)$ and highly correlated with $\mathrm{Pb}(\mathrm{r}=0.8538), \mathrm{Cu}(\mathrm{r}=0.9231)$, As $(\mathrm{r}=0.9529)$ and $\mathrm{Ni}(\mathrm{r}=0.8653)$. $\mathrm{Cr}$ was highly correlated with $\mathrm{Zn}(\mathrm{r}=0.912), \mathrm{Cu}(\mathrm{r}=0.824)$ and $\mathrm{Ni}(\mathrm{r}=0.81)$ and moderately correlated with $\mathrm{Ca}(\mathrm{r}=0.71)$. Mn was strongly correlated with As $(0.8662)$ and moderately correlated with $\mathrm{Fe}(\mathrm{r}=0.741)$. This strong correlation among metals shows that they originate from common source along the highway; traffic source.

\subsection{Enrichment Factor Analysis}

The result obtained for enrichment factors (EFs) is presented in Table 4. Cd, $\mathrm{Pb}, \mathrm{Zn}, \mathrm{Cu}$ and As were significantly enriched with EFs of 11413.37, 104.124, 427.378, 830.879 and 719.147 respectively. High EFs (> 100) were obtained for $\mathrm{Cd}, \mathrm{Pb}, \mathrm{Zn}, \mathrm{Cu}$ and $\mathrm{As}$, indicating their anthropogenic origins. Among these elements, $\mathrm{Cu}$ is an additive in high-temperature lubricant and is present in brake linings, approximately $1-10 \%$ by weight [61], and it has been used successfully as a good tracer for wear emission of road traffic [62]. Zn is associated with wear tire debris because $\mathrm{Zn}$ is added to tires during vulcanization and is responsible for $1-2 \%$ of the tires by weight $[63,64]$ and emissions from vehicle exhaust and wear abrasion are both important sources of $\mathrm{Pb}$. Correlation analyses (Table 3) illustrated that $\mathrm{Cd}, \mathrm{Pb}, \mathrm{Zn}, \mathrm{Cu}$ and $\mathrm{As}$ are well correlated with ( $\mathrm{r}>0.75$ ), suggesting that, similar to $\mathrm{Cu}$, these metals along 
Table 4: Pearson's correlation matrix among the trace metals measured in wet deposition

\begin{tabular}{lllllllllll}
\hline & $\mathrm{Cd}$ & $\mathrm{Cr}$ & $\mathrm{Mn}$ & $\mathrm{Pb}$ & $\mathrm{Zn}$ & $\mathrm{Cu}$ & $\mathrm{As}$ & $\mathrm{Ca}$ & $\mathrm{Ni}$ & $\mathrm{Fe}$ \\
\hline $\mathrm{Cd}$ & 1 & & & & & & & & & \\
$\mathrm{Cr}$ & 0.7607 & 1 & & & & & & & & \\
$\mathrm{Mn}$ & 0.7823 & 0.599 & 1 & & & & & & & \\
$\mathrm{~Pb}$ & 0.8538 & 0.685 & 0.5747 & 1 & & & & & & \\
$\mathrm{Zn}$ & 0.672 & 0.912 & 0.5881 & 0.5708 & 1 & & & & & \\
$\mathrm{Cu}$ & 0.9231 & 0.824 & 0.6627 & 0.9559 & 0.7547 & 1 & & & & \\
$\mathrm{As}$ & 0.9529 & 0.666 & 0.8662 & 0.6929 & 0.5832 & 0.7768 & 1 & & & \\
$\mathrm{Ca}$ & 0.6734 & 0.713 & 0.6855 & 0.7632 & 0.8333 & 0.8371 & 0.5411 & 1 & & \\
$\mathrm{Ni}$ & 0.8653 & 0.81 & 0.5749 & 0.9114 & 0.5946 & 0.9233 & 0.7374 & 0.6383 & 1 & \\
$\mathrm{Fe}$ & 0.6613 & 0.63 & 0.741 & 0.7227 & 0.7771 & 0.7978 & 0.5549 & 0.987 & 0.5855 & 1 \\
\hline
\end{tabular}

Significance level of 0.05

Ogbomoso section of Ibadan-Ilorin highway originated mainly from wear-abrasive sources. This showed that they are contributed primarily by traffic emissions, rather than a natural origin. This is in concert with previous results [54, 65-67].

$\mathrm{Cr}$ and $\mathrm{Ni}$ were moderately enriched by anthropogenic activities with EFs of 42.745 and 5.408 respectively. EFs (>10) was obtained for $\mathrm{Cr}$, which was well correlated with $\mathrm{Cu}(\mathrm{r}>0.75)$, this suggests its anthropogenic origin. $\mathrm{Mn}$ and $\mathrm{Ca}$ were not enriched by anthropogenic sources due to very low EFs of 1.239 and 0.743 respectively, Enrichment factor of $\mathrm{Ca}$ was close to unity, which suggest that a dust source could account for at least half of the aerosol Ca budget. The EF values obtained for Ca was consistent with the results observed by Lin et al., [68] at Hsuehshan Tunnel in Taiwan. The authors found out that $\mathrm{Ca}$ originated mainly from the resuspension of soil and road dust.

The values showed that in the most cases, the heavy metals in wet precipitation had anthropogenic origins. This result is similar to the results obtained in by Farahmandkia et al.,[66], where the heavy metals in precipitation had anthropogenic origins. Elements of anthropogenic origins ( $\mathrm{Cd}, \mathrm{Pb}, \mathrm{Zn}, \mathrm{Cu}$ and $\mathrm{As}$ ) were highly enriched with respect to crustal composition indicating the influence of anthropogenic input for these metals. Iron (Fe), which is considered an important crustal element, correlated well with $\mathrm{Ca}(\mathrm{r}=0.9875$, Tables 3.), demonstrating that crustal source is the major source of Fe. This is different from the results obtained Lin et al., [68] at Hsuehshan Tunnel in Taiwan where wear dust was the major anthropogenic source of Fe in Hsuehshan Tunnel.

\section{CONCLUSION}

We have reported wet deposition samples collected along a heavily trafficked highway in Ogbomoso, Nigeria. The wet deposition flux of aerosol ranged from 0.4461 to $0.6015 \mu \mathrm{g} / \mathrm{m}^{2} /$ day. The peak values in the concentrations of the heavy metals were typically observed at Takie with the highest traffic density. The Pearson's correlation matrix among the trace metals measured in wet deposition along the highway ranged from 0.7547- 0.9875. All positive and strong correlations indicate relationship among the trace metals in the same trend such that increase in the concentration of any suggests increase in concentration of the other. Enrichment factor ranged from 0.76 - 11413.37. $\mathrm{Cd}, \mathrm{Pb}, \mathrm{Zn}, \mathrm{Cu}$ and As were highly enriched with respect to crustal composition indicating the influence of anthropogenic input for these metals. Several of our observations also support the need for extended observations and analysis of these heavy metals in the urban environment.

\section{Acknowledgements}

The authors gratefully acknowledge the staff of Centre for Energy Research and Development (CERD) at Obafemi Awolowo University, Ile Ife, Nigeria, for the analysis.

\section{AUHORS BIOGRAPHIES}

Adejoke OluseyiAlamu, is currently a Doctoral student in the Department of Chemical Engineering Ladoke Akintola University of Technology, Ogbomoso, Nigeria. she also, had her first and second degree from same Department. She carried out the field work. 
Abass O. Alade, is Senior Lecturer in the Department of Chemical Engineering Ladoke Akintola University of Technology, Ogbomoso, Nigeria. He was awarded PhD in Biotechnolgy Engineering from International Islamic University Malaysia (IIUM), Malaysia. He has been teaching and researching for over 14years. He won Gold and Silver Medals: IIUM Research, Innovation and Invention Exhibition (IRIIE 2102 and 2013 respectively), IIUM, Malaysia. He is member of Bioenvironmental, water and Engineering Research Group (BWERG). Ladoke Akintola University of technology, Ogbomoso, Nigeria. he is a certified Engineer. He co-supervised the research work

Sunday Adekunle Adebanjo, is a lecturer in the Departmentof Chemical engineering, Lagos state University; he was awarded the doctor of Philosophy Degree in Chemical Engineering from Ladoke Akintola University of Technology, Ogbomoso, Nigeria. he is a corporate member of both Nigerian Society of Engineers (NSE) and Nigerian Society of Chemical Engineers (NSChE) respectively. He is a certified Engineer by Council for the Regulation of Engineering in Nigeria (COREN) and a consultant in air quality and life cycle analysis. He along the supervisors and edited the manuscript.

Lukuman Adekilekun Jimoda, received his PhD in Chemical Engineering from Obafemi Awolowo University Ile-Ife Nigeria. He is a Professor of Chemical Engineering in te Department of Chemical Engineering ladoke Akintola University of Technology, Ogbomoso, Nigeria. he has over 20 years of teaching and research. He is a certified Engineer and consultant in air quality and life cycle analysis. He supervised the research work

\section{REFERENCES}

[1]. Tsai YI, Cheng MT. Characterization of Chemical Species in Atmospheric Aerosols in a Metropolitan Basin. Chemosphere. 2004;54:1171-1181.

[2]. Park SS, Kim YJ. Source Contributions to Fine Particulate Matter in an Urban Atmosphere. Chemosphere. 2005;9:217-226

[3]. Fang GC, Wu YS, Chang SY, Huang SH, Rau JY. Size Distributions of Ambient Air Particles and Enrichment Factor Analyses of Metallic Elements at Taichung Harbor near the Taiwan Strait. Atmospheric Research. 2006;81:320-333.

[4]. Chang SH, Wang KS, Chang HF. et al Comparison of Source Identification of Metals in Road-dust and Soil. Soil Sediment Contamination. 2009;18:669-683.

[5]. Cheng MC, You CF, Lin FJ, Huang KF, Chung CH. Sources of $\mathrm{Cu}, \mathrm{Zn}, \mathrm{Cd}$ and $\mathrm{Pb}$ in Rainwater at a Subtropical islet Offshore, Northern Taiwan. Atmospheric Environment. 2011;45: 1919-1928.

[6]. Arditsoglou A, Samara C. Levels of Total Suspended Particulate Matter and Major Trace Elements in Kosovo: A Source Identification and Apportionment Study. Chemosphere. 2005;59:669-678.

[7]. Shaheen N, Shah MH, Jaffar M. A Study of Airborne Selected Metals and Particle Size Distribution in Relation to Climatic Variables and Their Source Identification. Water, Air, and Soil Pollution. 2005;164:275294.

[8]. Shah MH. Atmospheric Particulate Matter: Trace Metals and Size Fractionation. VDM Verlag Dr. Muller, Saarbrucken. 2009;228.

[9]. WHO. Health aspects of air pollution with particulate matter, ozone and nitrogen dioxide. World Health Organization. Copenhagen. 2003;94.

[10]. Valavanidis A, Fiotakis K, Vlahogianni T. Characterization of Atmospheric Particulates, Particle bound Transition Metals and Polycyclic Aromatic Hydrocarbons of Urban Air in the Centre of Athens (Greece). Chemosphere. 2006;65:760-768.

[11. Magas OK, Gunter JT, Regens JL. Ambient Air Pollution and Daily Pediatric Hospitalizations for Asthma. Environmental Science and Pollution Research. 2007;14:19-23.

[12]. Cao YZ, Wang SY, Zhang G, Luo JY, Lu SY. Chemical Characteristics of Wet Precipitation at an Urban Site of Guangzhou, South China. Atmospheric Research. 2009;94:462-469.

[13]. Chiou P, Tang W, Lin CJ, Chu HW, Ho TC. Comparison of Atmospheric Aerosols between Two Sites over Golden Triangle of Texas. International Journal of $\quad$ Environmental Research. 2009;3:253-270.

[14]. Wild P, Bourgkard E, Paris C. Lung Cancer and Exposure to Metals: The Epidemiological Evidence. Method Molecular Biology. 2009;472:139-167.

[15]. Taghinia Hejabi A, Basavarajappa HT, Qaid Saeed AM. Heavy Metal Pollution in Kabini River Sediments. International Journal of Environmental Research. 2010;4:629-636 
[16]. Sekhavatjou MS, Hoseini AA, Rostami A. Comparison of Trace Element Concentrations in Ambient Air of Industrial and Residential Areas in Tehran City. Biological Trace Elements Research. 2011;8:335-346.

[17]. Hosseini AA, Sekhavatjou MS, Hassanzadeh KB, Karbassi AR. Bioaccumulation of Trace Elements in Water, Sediment, and Six Fish Species from a Freshwater Wetland, Iran. Microchemical Journal. 2012;104:16.

[18]. Pirjola L, Lähde T, Niemi, JV. et al Spatial and Temporal Characterization of Traffic Emissions in Urban Microenvironments with a Mobile Laboratory. Atmospheric Environment. 2012; 63:156-167.

[19]. Soares J, Kousa A, Kukkonen J. et al. Refinement of a Model for Evaluating the Population Exposure in an Urban Area. Geoscience Model Development. 2014;7:1885-1872.

[20]. Ana Paula G, Fontenele AF, Jairo JP. Measurements of Heavy Metals in Dry and Wet Deposition in São Paulo City. 2010; Article . January DOI: 10.1007/978-90-481-3043-6_12 https://www.researchgate.net/publication/251120734

[21]. Davis BS Birch GF. Spatial Distribution of Bulk Atmospheric Deposition of Heavy Metals in Metropolitan Sydney, Australia. Water, Air and Soil Pollution. 2011;214:147-162.

[22]. Xia L Gao Y. Characterization of Trace Elements in $\mathrm{PM}_{2.5}$ Aerosols in the Vicinity of Highways in Northeast New Jersey in the U.S. East Coast. Atmospheric Pollution Research. 2011;2:34-44.

[23]. Massoli P, Fortner EC, Canagaratna MR. et al. Pollution Gradients and Chemical Characterization of Particulate Matter from Vehicular Traffic near Major Roadways: Results from the 2009 Queens College Air Quality study in NYC, Aerosol Science and Technology. submitted, 2012.

[24]. Aurela M, Saarikoski S, Niemi JV. et al. Chemical and Source Characterization of Submicron Particles at Residential and Traffic Sites in the Helsinki Metropolitan Area, Finland. Aerosol and Air Quality Research. 2014;10:1-14.

[25]. Islam MdF, Majumder SS, Al Mamun A, Khan MdB, Rahman MA, Salam A. Trace Metals Concentrations at the Atmosphere Particulate Matters in the Southeast Asian Mega City (Dhaka, Bangladesh). Open Journal of Air Pollution. 2015;4:86-98.

[26]. Ojo OOS, Awokola OS. Investigation of Air Pollution from Automobiles at Intersections on Some Selected Major Roads in Ogbomoso, South Western, Nigeria. IOSR Journal of Mechanical and Civil Engineering. 2012;1:31-35.

[27]. Adelasoye KA, Alamu LO. Accumulation of Heavy Metal Pollutants in Soil and Vegetation and their Effects on Soil Microbial Population on Roadsides in Ogbomoso, Nigeria. Journal of Environmental Science and Water Resources. 2016;5:1-7.

[28]. Adeboyejo AT, Abolade O, Oshinowo T. The Prevalence of Environment Related Diseases in Peri-Urban Areas of Ogbomoso. Ethiopian Journal of Environmental Studies and Management. 2009;2:73-83.

[29]. Jimoda LA, Sonibare JA, Akeredolu FA. Wet and Dry Deposition Studies of Aerosol Hazes Around a Major Sawdust Open Burning Area. Ife Journal of Technology. 2010;19:100-106.

[30]. Mohammad Y. Atmospheric Deposition of Heavy Metals in Toronto, Master Thesis, Department of Molecular Science, Ryerson University, Toronto, Ontario, Canada. 2012

[31]. Wetang'ula GN, Wamalwa HM. Trace Elements in Rainfall Collected around Menengai Area Kenya: Proceedings, World Geothermal Congress, 201 Melbourne, Australia. Geothermal Development Co. Limited, P.O. Box 100746-00100, Nairobi Kenya. 2015

[32]. Pan YP, Wang YS. Wet and Dry Deposition of Trace Elements in Northern China. Atmospheric Chemistry and Physics. 2015;15:951-972.

[33]. Sakata M, Tani Y, Takagi T. Wet and Dry Deposition Fluxes of Trace Elements in Tokyo Bay. Atmospheric Environment. 2008;42:5913-5922.

[34]. European Standard EN 15841 . Ambient Air Quality Standard Method for Determination OF Arsenic, Cadmium, Lead and Nickel in Atmosphere Deposition. 2009

[35]. Soriano A, Pallarés S, Pardo F, Vicente AB, Sanfeliu T, Bech J. Deposition of Heavy Metals from Particulate Settleable Matter in Soils of an Industrialised Area. Journal of Geochemical Exploration. 2012;113:36-44.

[36]. Melaku S, Morris V, Raghavan D, Hosten C. Seasonal Variation of Heavy Metals in Ambient Air and Precipitation at a single site in Washington, DC. Environmental Pollution. 2008;155:88-98.

[37]. Sharma RK, Agrawal M, Marshall FM. Atmospheric Deposition of Heavy metals ( $\mathrm{Cu}, \mathrm{Zn}, \mathrm{Cd}$ and $\mathrm{Pb})$ in Varanasi City, India. Environmental Monitoring and Assessment. 2008;142:269-278.

[38]. Anf HZ, Emad S. An Environmental Impact Assessment of Open Burning of Scrap Tyres. Journal of Applied Science 2014;14:2695-2703

[39]. Safai PD, Rao PSP, Momin GA, Ali K, Chate DM, Praveen PS. Chemical Composition of Precipitation during 1984 - 2002 at Pune, India. Atmospheric Environment. 2004;38: 1705-1714.

[40]. Zhang M, Wang S, Wu F, Yuan X, Zhang Y. Chemical Composition of Wet Precipitation and Anthropogenic Influence at a Developing Urban Site in Southeastern China. Atmospheric Research. 2007;84:311-322.

(C) 2020 Faculty of Engineering, Lagos State University, Ojo. Nigeria. All rights reserved. 
[41]. Cocker DR. Na K Characterization and Source Identification of Trace Elements in $\mathrm{PM}_{2.5}$ from Mira Loma, Southern California. Atmospheric Research. 2009;93:793-800.

[42]. Nazir R, Shaheen N, Shah MH. Indoor/Outdoor Relationship of Trace Metals in the Atmospheric Particulate Matter of an Industrial Area. Atmospheric Research. 2011;101: 765-772.

[43]. Dubey B, Pal AK, Singh G. Trace Metal Composition of Airborne Particulate Matter in the Coal Mining and Non-mining Areas of Dhanbad Region, Jharkhand, India. Atmospheric Pollution Research. 2012;3:238-246.

[44]. Koulousaris M, Aloupi M, Angelidis MO. Total metal concentration in atmospheric precipitation from the Northern Agean Sea. Water, Air and Soil Pollution. 2009;201:389-403.

[45]. WHO. Guidelines for Air Quality. World Health Organization. Geneva 2003

[46]. ATSDR, Agency for Toxic Substances and Disease Registry. Toxic Substances Portal. October 18, 2017. http://www.atsdr.cdc.gov/substances/index.asp (accessed October 2017).

[47]. EPA. National Ambient Air Quality Standards for Particulate Matter: Final Rule 2013 Federal Registry 2013

[48]. Fatoba PO, Ogunkunle CO, Olawepo GK. Assessment of Atmospheric Metal Depositions in the Industrial Areas of the Southwest of Nigeria. Ethiopian Journal of Environmental Studies and Management. 2012;5:260-267.

[49]. Moaref S, Sekhavatjou MS Hosseini AA. Determination of Trace Elements Concentration in wet and dry Atmospheric Deposition and Surface soil in the Largest Industrial city, Southwest of Iran. International Journal of Environmental Research. 2014;8:335-346.

[50]. Scerbo R, Ristori T, Possenti L, Lampugnami L, Barale R Barghigiani C. Lichen (Xanthoria parientina) Biomonitoring of Trace Element Contamination and Air Quality Assessment in Pisa Province, Italy. Science -Total Environment. 2001;286:27-40.

[51]. Gunawardena J, Egodawatta P, Ayoko GA, Goonetilleke A. Role of Traffic in Atmospheric Accumulation of Heavy Metals and Polycyclic Aromatic Hydrocarbons. Atmospheric Environment. 2012;54: 502-510.

[52]. Olowoyo JO, van Heerden E. Trace Element Concentrations from Lichen Transplants in Pretoria, South Africa. Environmental Science and Pollution Research. 2010;DOI 10.1007/s11356-010-0410-3

[53]. Meena M, Meena BS, Chandrawat U, Rani A. Characterization of Wet and Dry Deposition at an Industrial City of Western India. International Journal of Innovative Research in Science, Engineering and Technology. 2014;3:9050-9056.

[54]. Bai J, Cui B, Wang Q, Gao H, Ding Q. Assessment of heavy metal contamination of roadside soils in Southwest China. Stochastic Environmental Research and Risk Assessment. 2008;23:341-347.

[55]. Councell T, Duckenfield K, Landa ER, Callender E. Tire-Wear Particles as a Source of Zinc to the Environment. Environment Science and Technology. 2004;38:4206-4214.

[56]. Adedeji OH, Olayinka OO, Oyebanji FF. Assessment of Traffic Related Heavy Metals Pollution of Roadside Soils in Emerging Urban Centres in Ijebu-North Area of Ogun State, Nigeria. Journal of Applied Science and Environmental Management. 2013;17:509-514.

[57]. Farmaki EG, Thomaidis NS. Current Status of the Metal Pollution of the Environment of Greece- a review.Global Nest. 2008;10:366-375.

[58]. Wang LK, Chen JP, Hung Y, Shammas NK. Heavy Metals in the Environment. CRC Press, Taylor \& Francis Group, Boca Raton, 2009;FL. ISBN-13: 978-1-4200-7316-4.

[59]. Cempel M, Nikel G. Nickel: A Review of Its Sources and Environmental Toxicology. Polish Journal of Environmental Studies. 2006;15:375-382.

[60]. Adefemi OS, Olaofe D, Asaolu SS. Seasonal Variation in Heavy Metal Distribution in the Sediment of Major Dams in Ekiti State. Pakistan Journal of Nutrition. 2007;6:705-707

[61]. Vallius M. Characteristics and sources of fine particulate matter in urban air. Publications of the National Public Health Institute, Department of Environmental Health Kuopio, Finland. 2005;79.

[62]. Sanders PG, Xu N, Dalka TM, Maricq MM. Airborne Brake Wear Debris: Size Distributions, Composition, and a Comparison of Dynamometer and Vehicle Tests. Environmental Science and Technology. 2003;37:4060-4069.

[63]. Pio C, Mirante F, Oliveira C. et al. Size-segregated Chemical Composition of Aerosol Emissions in an Urban Road Tunnel in Portugal. Atmospheric Environment. 2013;71:15-25.

[64]. Degaffe FS, Turner A. Leaching of Zinc from Tire Wear Particles under Simulated Estuarine Conditions. Chemosphere. 2011;85:738-743.

[65]. Taheri S, Khoshgoftarmanesh AH, Shariatmadari H, Chaney RL. Kinetics of Zinc Release from Ground Tire Rubber and Rubber Ash in a Calcareous Soil as Alternatives to Zn Fertilizers. Plant Soil. 2011;341:89-91

[66]. Tanner PA, Hoi-Ling M, Yu PKN. Fingerprinting Metals in Urban Street Dust in Beijing, Shanghai and Hong Kong. Environmental Science and Technology. 2008;42:7111-7117. 
[67]. Farahmandkia Z, Mehrasbi MR, Sekhavatjou MS. Relationship between Concentration of Heavy Metals in Wet Precipitation and Atmospheric $\mathrm{PM}_{10}$ Particulate IN Zahajan, Iran. Iranian Journal of Environmental Health Science and Engineering. 2011;8:49-56

[68]. Harrison RM, Jones AM, Gielt J, Yin, J, Green DC. Estimation of the Contributions of Brake Dust, Tire Wear, and Re-suspension to Non-exhaust Traffic Particles Derived from Atmospheric Measurements. Environmental Science and Technology. 2012;46:6523-6529. 